Katolicki Uniwersytet Lubelski Jana Pawła II

Wydział Nauk Humanistycznych

Katedra Literatury Rosyjskiej

tel.: +48 814454310

e-mail: monika.sidor@kul.pl

\title{
Prawość i cierpienie. Rosyjska wersja świętości kobiecej w twórczości Aleksandra Sołżenicyna
}

Słowa kluczowe: kobieta, świętość, „prawiednik”, szaleniec Chrystusowy

„Ludzie zapomnieli Boga - i stąd to wszystko" [Солженицын 1995, 447] - tak w słynnej mowie Templtownowskiej określał Sołżenicyn przyczynę wszelkich współczesnych nieszczęść - począwszy od wojen, a skończywszy na konfliktach społecznych i problemach socjalnych. Tymi samymi słowami lud rosyjski zwykł komentować tragedie, które w przeszłości dotykały Rosję. Autor Czerwonego Koła (Красное Колесо, 1971-1991) stwierdził zaś, że formuła ta może służyć jako uniwersalne wyjaśnienie najbardziej palących problemów całego świata.

Sołżenicyn pozostawił po sobie sławę moralisty i wiernego obrońcy prawdy, stąd też naturalne jest poszukiwanie w jego utworach przesłania etycznego, które było już wielokrotnie przedmiotem badań polskich naukowców [Suchanek 2013, 317-330; Żejmo 2000, 96-159; Przebinda 2003, 187-236; Kowalska 2011] jednak wiele aspektów tego zagadnienia ciągle czeka na dostrzeżenie i interpretację. Trzeba przyznać, że kwestie etyczne w twórczości Sołżenicyna są raczej rzadko odczytywane w perspektywie religijnej, częściej mówi się o humanizmie czy tradycyjnej moralności ludowej [Przebinda 2003, 197-200; Żejmo 2000, 95-104]. Wypada jednak zauważyć, że od lat 70. prozaik oficjalnie określał się jako wyznawca prawosławia i aktywnie włączał się w pracę na rzecz zachowania identyfikacji 
religijnej swoich rodaków ${ }^{1}$. Te właśnie wysiłki zostały dostrzeżone na Zachodzie i stały się powodem przyznania Sołżenicynowi nagrody im. Templtona. W związanym z uroczystością wręczenia owego wyróżnienia przemówieniu, którego fragment był tu wcześniej cytowany, Sołżenicyn przyznał, że został wychowany w duchu prawosławia i boleje nad statusem religijności we współczesnym świecie, a w szczególności w państwie sowieckim [Солженицын 1995, 447]. W owych rozważaniach pisarz potwierdził również, że zagadnienia religijne były zawsze obecne w jego twórczości. Jednym z ciągle mało zbadanych problemów dotyczących tej strony spuścizny autora Oddziału chorych na raka (Paковый корnyc, 1968) jest kwestia świętości kobiecej, która w ostatnich czasach wydaje się bardzo aktualna w związku z rozwojem badań nad problemami tożsamości kobiet czy płci kulturowej. Przy okazji warto wspomnieć, że według tego ostatniego podejścia Sołżenicyn jest uważany za pisarza męskiego, w twórczości którego dominuje maskulinistyczny punkt widzenia świata [Темпест 2013, 454]. Nie ulega jednak wątpliwości, że obraz kobiety i związane z nim zagadnienia kulturowe przyciągały uwage twórcy i jego dzieła zawierają wiele kunsztownie skonstruowanych postaci kobiecych.

Jeśli chodzi o Sołżenicynowskie podejście do kwestii świętości, to podobnie jak w wielu innych zagadnieniach, pisarz pozostaje zasadniczo wierny ujęciu tradycyjnemu, które ma swoje początki w kulturze staroruskiej i tradycji religijno-ludowej [У рманов 2005, 376]. W jego utworach widoczne są przecież odwołania do ukształtowanego w ten sposób typu duchowości na poziomie tematów, motywów, stylu i sposobu widzenia świata [Урманов 2000, 50]. Mimo że rzadko ukazuje on świętość w z perspektywy stricte religijnej, to na pewno w jego ujęciu pobrzmiewa długa tradycja hagiograficzna i uformowana przez wieki w prawosławnej kulturze rosyjskiej. Przypomnijmy, że przemożne dążenie do osiągnięcia zbawienia zostało utrwalone już w zabytkach piśmiennictwa staroruskiego [Топоров 1995, 7-11; Andrusiewicz 1994, 80-85; Аверинцев 1988, 215-216]. Naukowe zaś próby systematyzacji postaci świętych ruskich, którzy zostawili trwały ślad w kulturze, zaowocowały propozycjami swoistych typologii świętości, gdzie, mimo różnorodności podejść badawczych, można wyróżnić pewne stałe elementy, na przykład wzorce: księcia, mnicha, męczennika w imię Chrystusa czy „jurodiwego". Wraz z rozwojem prawosławia na Rusi zestaw typów świętości powiększał się, a proces ten przebiegał nieprzerwanie, mimo różno-

1 Dowodem tej działalności jest szereg wystąpień publicystycznych, zapoczątkowanych przez List do Patriarchy Pimena. 
rakich zawirowań historycznych. Badania nad wzorcami osobowymi świętych w kulturze rosyjskiej były z tych samych, historycznych, powodów bardzo utrudnione, niemniej jednak prowadzono je nawet w niezwykle niesprzyjających warunkach porewolucyjnych [Charewicz 2013, 130-132]. Popularyzacja wzorców osobowych świętych i same rozważania na temat duchowości rosyjskiej swobodniej mogły rozwijać się na emigracji, gdzie powstawały i były wydawane nie tylko w różnym stopniu beletryzowane, rozmaite nowe wersje żywotów świętych, tworzonych nieraz przez znanych pisarzy, ale także prowadzono ożywione badania nad samą istotą rosyjskiej świętości czy to w perspektywie teologicznej, czy kulturowej, czy wreszcie obyczajowo-mentalnościowej [Sidor 2009, 79-82].

Po upadku ZSRR ów kierunek refleksji naukowej bardzo się rozwinął i nadal ma przed sobą długą perspektywę rozwoju [Charewicz 2013, 130]. Warto zauważyć, że w dotychczasowych ujęciach tematu w galerii ruskich świętych trudno doszukać się szczególnej roli postaci kobiecych. Georgij Fiedotow w swej fundamentalnej pracy Święci Dawnej Rusi (Cвятье древней Pуси) podaje, że cerkiew rosyjska czciła tylko 12 świętych-kobiet. Badacz zauważa przy tym, że większość z obdarzanych kultem należała do rodów książęcych i nie wyróżniała się osobliwym heroizmem cnót [Федотов 1990, 215-217]. Joann Kołogriwow w powstałym w latach 60. opracowaniu odnotowuje zaś tylko pięć świętych-kobiet, z czego tylko trzy przypadki określa jako udokumentowane. Niemniej badacz sam zauważa, że religijność ludowa uzupełnia tę listę następnymi imionami, bez względu na to, czy ich prawdziwość historyczna jest udowodniona [Кологривов 1961, 251]. Kołogriwow jest skłonny przypisywać skromną liczbę kobiet wśród rosyjskich świętych mentalnej spuściźnie po jarzmie mongolskim, ale dopuszcza także taką ewentualność, że wśród wiernych prawosławnych na Rusi po prostu nie było kobiet zasługujących na otaczanie szczególną czcią [Кологривов 1961, 256]. Można zdaje się dodać jeszcze, że kwestia płci świętych nie stanowiła zwykle szczególnego przedmiotu zainteresowania hagiografów. Z jednej strony, historyczny podział ról społecznych nie budził wątpliwości, a z drugiej, wydaje się, że nikt nie miał zamkniętej drogi do świętości. To przecież księżna Olga, nazwana „równą apostołom”, według podań była pierwszą osobą spośród ruskich książąt, która przyjęła chrzest [Sidor 2012, 420]. Zainteresowanie problemem kobiecej świętości w dawnej rosyjskiej kulturze duchowej pojawia się więc dopiero ex post, z perspektywy wieków późniejszych.

Trzeba jeszcze dodać, że naturalne nawarstwianie się kulturowych przekazów o świętych, powstawanie nowych wersji żywotów i uzupełnianie galerii świętych przez nowe postaci zostało w Rosji później gwałtownie zahamo- 
wane przez wydarzenia historyczne. Nie będziemy wgłębiać się w niezwykle trudną sytuację, z jaką spotkała się Cerkiew Prawosławna po rewolucji bolszewickiej, kiedy wielka rzesza wiernych i duchownych znalazła się na emigracji, warto jednak podkreślić tragiczne konsekwencje kulturalne sztucznego odrzucenia w oficjalnym dyskursie radzieckim duchowych podstaw światopoglądowych. Mimo że, jak dowodzą źródła historyczne, praktyka uznawania świętości nie została zawieszona i wśród kandydatów do grona świętych dodawano ciągle nowe postaci, to proces ich wprowadzania do ogólnego strumienia kultury został zupełnie powstrzymany. O ile bowiem emigranci rosyjscy, jak to już zostało zauważone, z wielką atencją pielęgnowali pamięć o swoich duchowych korzeniach i chętnie odwoływali się do kanonizowanych przez cerkiew postaci, to w Związku Radzieckim cała gałąź religijnej twórczości artystycznej została zupełnie zlikwidowana. Żywoty świętych w oficjalnej kulturze nie mogły być niczym więcej niż zabytkami literackimi, a nowi „prawiednicy” nie znajdowali miejsca w kulturze zdominowanej przez socrealizm.

W okresie, gdy Sołżenicyn zdobywa swoje pisarskie szlify, postaci świętych po prostu nie istnieją w literaturze, wyparte przez nowy typ bohatera socjalistycznego. Przyszły laureat nagrody Nobla zrazu zdaje się nie odczuwać z tego powodu specjalnych niedogodności. Sposób widzenia świata, jaki autor Jednego dnia Iwana Denisowicza reprezentuje w czasie swego debiutu literackiego zupełnie koresponduje z założeniami socrealizmu i próżno udowadniać, że w pierwszych utworach pisarz reprezentował inny model twórczości artystycznej. Niemniej jednak, warto zauważyć, że pozostając w kręgu panującej podówczas doktryny literackiej, Sołżenicyn uwzględniał w swojej twórczości także idee odwołujące się do ludowego sytemu wartości, osadzonego głęboko w tradycjach prawosławnych.

W spuściźnie artystycznej rosyjskiego pisarza dwudziestowiecznego spotykamy więc wypracowany przez literaturę staroruską model świętości kobiecej, podkreślający wagę codziennej pracy na rzecz innych. Wśród czytelników i krytyków twórczości Sołżenicyna panuje przekonanie, że najbliższa temu typowi rosyjskiej świętości jest Matriona Wasiliewna - bohaterka utworu Zagroda Matriony (Матренин двор, 1963), a to dzięki odwołaniu do mądrości ludowej, zawartej w tekście opowiadania: „nie stoi sioło bez prawiednika” [Suchanek 1994, 39]. Zaraz po publikacji owego utworu wśród wpływowych krytyków literackich i czytelników wybuchła dyskusja nad oceną świata duchowego bohaterki i istnieniem odwołań religijnych w utworze. Przy przesłaniu ogólnie zgodnym z ideami socrealizmu Sołżenicyn postąpił raczej ryzykownie, umieszczając w zakończeniu dzieła odwołanie do „prawiedniczestwa". Władimir Łakszyn, biorąc niejako z urzędu - jako jeden 
z redaktorów miesięcznika „Nowyj mir”, gdzie opowiadanie się ukazało w obronę utwór i zamysł artystyczny Sołżenicyna zauważył:

Близоруких критиков смутило и перепугало слово «праведник» - так пугались слова «жупел» купчихи у Островского. Можно, конечно, спорить относительно умесности применения автором этого слова - слишком сросся с ним религиозно-поучительский смысл [Лакшин 2009, 83-85].

Wprowadzenie do utworu wyraźnej perspektywy religijnej dyskryminowałoby nie tylko samo dzieło, ale także i wydawcę, który takowe treści dopuściłby do druku. Łakszyn więc w swoich artykułach krytycznoliterackich odnoszacych się do Zagrody Matriony powołuje się obficie na odpowiednie wypowiedzi Lenina i stwierdza jednoznacznie: „Матрена - прежде всего труженица" [Лакшин 2009, 85].

Przychylni Sołżenicynowi krytycy podkreślali więc, że Matriona nie jest religijna, zachowuje jedynie niektóre ludowe obyczaje, a ogólnie reprezentuje najcenniejszą - bo zdrową moralnie - cząstkę społeczeństwa socjalistycznego ${ }^{2}$. W rzeczy samej nie można oderwać Matriony od warunków historycznych, w której przyszło jej żyć. Z tym, że warunki te, jak się wydaje, nie stanowią o charakterystyce wewnętrznej bohaterki, a tylko ją uzupelniaja ${ }^{3}$. Z drugiej strony, zaakcentowanie w postaci Matriony cech właściwych osobom wyniesionym na ołtarze wcale nie implikuje pełnej realizacji ideału. Sołżenicyn nie przedstawia bowiem świętości odizolowanej od życia, właściwej ikonowym wyobrażeniom świętych, których wzrok utkwiony jest w inną, niebiańską rzeczywistość. Indywidualny czyn heroiczny - „podwig", który według zasad kościelnych jest powodem uznania danej osoby za święta - pisarz przedstawia jako codzienne życie, pełne trosk i pracy. Sołżenicyn u właścicielki talnowskiej zagrody uwydatnia cechy znane na przykład z siedemnastowiecznego żywotu Julianii Osorinej Łazariewskiej. Bohaterka Zagrody Matriony odznacza się wielką pokorą w przyjmowaniu nieszczęść życiowych. Godzi się na przykład z zaginięciem męża i śmiercią dzieci. Taka sama żałoba, przypomnijmy, jest także elementem wyeksponowanym przez Drużynę Osorina w opowieści o jego matce [Łużny, 1971, 134]. Godny podziwu jest także trud, jaki Matriona wkłada w organizację swojego codziennego życia, w przygotowanie opału, zebranie paszy dla kozy czy

\footnotetext{
2 Fragmenty artykułów krytycznoliterackich z tego okresu patrz w: [Лакшин 2009, 82].

3 W rozważaniach o specyficznym kobiecym typie „prawiednika” rozwinięte zostały niektóre myśli przedstawione w artykule: Aktualizacja staroruskiego obrazu świeckiego naśladowcy Chrystusa w postaciach kobiecych prozy dwudziestowiecznej (utwory Aleksego Riemizowa i Aleksandra Sotżenicyna) [Sidor 2012, 426-427].
} 
zgromadzenie zapasów na zimę. Żmudne te obowiązki, które - jak pisze narrator - nie omijają nikogo w Talnowie, Matriona wykonuje bez szemrania, nie tracąc pogody ducha. Bohaterka utworu cierpi z powodu nawracającej choroby, a jednak nie odmawia nigdy bezinteresownej pomocy. Chętnie wspiera swoją pracą sąsiadki i nie żałuje wysiłku nawet w kołchozie, mimo świadomości panujących tam nadużyć. Bez względu na zepsucie otaczającego świata, Matriona pozostaje więc wierna pewnemu nienaruszalnemu systemowi wartości. Podejście do codzienności i gotowość pomocy innym jest dla Sołżenicyna podstawą do nazwania Matriony rosyjskim człowiekiem prawym -,prawiednikiem”. Wprowadzenie tego terminu do tekstu utworu nie było więc tylko zabiegiem stylistycznym - jak starali się to przedstawić ówcześni sowieccy obrońcy dzieła - ale w pełni świadomym wyborem pisarskim, uznającym heroizm cnót bohaterki i stawiającym ją w szeregu osób zasługujących na naśladowanie. Ciekawym rysem, który także ma znaczenie w kontekście naszych rozważań jest fakt, że świętość na Rusi często wiązała się z dobrowolnym przyjęciem odrzucenia i pogardy, a nawet pozornym szaleństwem [Wodziński, 2000, 20-21]. Ten aspekt świętości ujawnia się także u Sołżenicyna, gdyż po śmierci bohaterki, otoczenie piętnuje jej zbytnią gotowość do pomocy, naiwność, małe przywiązanie do majątku, a nawet nie waha się otwarcie zarzucić jej głupotę. W ten sposób Sołżenicyn zaznaczył osamotnienie Matriony, której wysiłki pozostały niezrozumiane przez otaczających ją ludzi. To osamotnienie jest uznawane przez badaczy zjawiska „szaleństwa Chrystusowego" za jeden z czołowych wyznaczników postawy świętego-jurodiwego [Лихачев, Панченко 1984, 4-5]. Przez wprowadzenie motywu naśmiewania się czy kpin ze sposobu życia zmarłej Matriony pisarz dwudziestowieczny zbliża się do konwencji żywotu „błogosławionego szaleńca”. Śmiech otoczenia bowiem, w literaturze hagiograficznej poświęconej tego typu postaciom, faktycznie, w ostatecznym rozrachunku, nie dotyka wyśmiewanej postaci i zwraca się przeciwko wyśmiewającym. Jurodiwy swoją śmiesznością, która jest grą z ogólnie przyjętymi normami, obnaża zaś nawet najgłębiej skrywane przywary społeczeństwa, pośród którego żyje i działa [Wodziński, 2000, 218-220].

W galerii kobiet występujących w utworach Sołżenicyna nie tylko właścicielka domu w Talnowie zasługuje na wspomnienie przy okazji rozważań nad heroizmem cnót. Warto wspomnieć tutaj także o postaciach kobiecych w powieści Krąg pierwszy (В круге первом, 1968). W pierwszym rzędzie należy zwrócić uwagę na dość zagadkową figurę Agnii, która stanowi ewidentne odwołanie do dawnych wzorców hagiograficznych [Лопухина-Родянко 1974, 102]. Sołżenicyn tak komponuje tę postać, aby od razu, od pierwszego pojawienia jej w utworze podkreślić maksymalizm etyczny dziewczyny. 
Эта девушка была откуда-то не с земли. По несчастью для себя, она была утончена и требовательна больше той меры, которая позволяет человеку жить [Солженицын 2009, 175].

Olivier Clément, omawiając wyznaczniki światopoglądu utrwalonego w dziełach Sołżenicyna, w opisach Agnii odnajduje echa kultu „Wiecznej Kobiecości" spod znaku Włodzimierza Sołowjowa [Clément 2012, 101]. Rzeczywiście cechy zewnętrzne dziewczyny i jej sposób bycia wyraźnie odróżniają ją od innych postaci utworu, uwikłanych w codzienność i skoncentrowanych na ziemskiej egzystencji. Doskonale tę odmienność Agnii odczuwa Jakontow, który, mimo pragmatycznego usposobienia i skonkretyzowanych planów na przyszłość, nie może oprzeć się jej dyskretnemu urokowi. System priorytetów Agnii zupełnie rozmija się z wartościami, które ceni Jakontow, lecz jej tajemniczość i czystość sprawiają, że właśnie tę postać przywołuje on we wspomnieniach po wielu latach - w chwili największego kryzysu wewnętrznego, będąc już wysokim przedstawicielem aparatu władzy. Agnia reprezentuje niewątpliwie odchodzący świat odrzuconych wartości prawosławnych. Bez widocznego powodu dziewczyna wychowana w środowisku ateistyznym angażuje się w życie religijne i odkrywa niebiańskie piękno nabożeństw cerkiewnych. Narzeczona Jakontowa nie poprzestaje jednak na czysto estetycznym zainteresowaniu wiarą, lecz czuje potrzebę przekazania tej swoistej „dobrej nowiny” innym. W ten sposób realizuje się zauważony przez Clémenta proces przekazywania wiary. Francuski teolog prawosławny zauważa bowiem, że kobiety rosyjskie od wieków spełniają rolę pokornych świadków i krzewicieli wiary - nowych apostołów:

Te kobiety - niektóre, zdaje się, że wiele z nich - przekazują społeczeństwu sowieckiemu dobroć, miłość czynną, których ono bardzo potrzebuje, a i nasza cywilizacja techniki, ideologii, narkotyków tak bardzo potrzebuje na Zachodzie, jak i na Wschodzie. W Rosji jednak kobiety odegrały szczególną rolę: one przekazały wiarę [Clément 2012, 90].

Cechy osobowości Agnii Sołżenicyn dodatkowo podkreślił przez znaczące imię, nawiązujące do sedna wiary chrześcijańskiej - ofiary Baranka. Dziewczyna jest nie tylko jedyną postacią w powieści, która świadomie opowiada się po stronie religii. Jednocześnie jest ona gotowa ponieść ofiarę zgadzając się na małżeństwo z Jakontowem. Jednak trzeba zauważyć, że poświęcenie, które zostało zapisane w imieniu Agnii jest cechą szeregu innych kobiet, występujących w utworze Sołżenicyna. Postać Agnii może być kluczem do interpretacji historii wielu żon więźniów ukazanych i lub tylko wspomnianych w fabule Kregu pierwszego. Narrator podkreśla tragizm losu 
towarzyszek życia skazańców, które muszą samotnie borykać się z trudami codzienności, znosić intrygi sąsiadów i wbrew presji otoczenia nie wyrzekać się mężów. Dobitnym przykładem jest Natalia Pawłowna Gierasimowicz, której już pierwsze pojawienie się w utworze zwraca uwagę narratora ku trudnej doli żony „wroga narodu”: „Глаза подведены впалыми обводками, у глаз и губ - морщины, кожа лица дряблая" [Солженицын 2009, 295].

Zewnętrzny i w istocie szczątkowy opis, ograniczający się tylko do twarzy, nawiązuje do malarstwa ikonowego. Jednak w danym przez Sołżenicyna portrecie nie ma nieziemskiego światła w oczach i nie ma nadziei, co pozwala uwydatnić martyrologię wszystkich kobiet reprezentowanych przez Natalię Pawłownę. Sołżenicyn przedstawia również krótką dramatyczną historię bohaterki, sprowadzającą się do ciągłego oczekiwania i strachu. W scenie więziennego widzenia z mężem Natalia wybucha płaczem, podkreślając, jak bardzo trudno jest jej akceptować swój los. Ta niewypowiedziana skarga nie może być interpretowana jako przejaw rezygnacji, ale warto ją skojarzyć z żalami biblijnego Hioba, bolejącego nad swym nieszczęściem, a zarazem gotowego dalej trwać w ufności względem Boga. Zrekapitulowana wcześniej przez narratora historia Natalii Pawłownej pozwala bowiem sądzić, że niezależnie od cierpień, jakie ją czekają, dalej będzie ona wiernie znosić rozstanie.

Kobiety doświadczone przez system sowiecki - pozostawione bez mężów i dźwigające na swoich barkach ciężar utrzymania rodziny, zmuszone do zachowania milczenia i utrzymania pozorów normalności, osamotnione i zdane wyłącznie na siebie - są w istocie męczennicami, które znoszą upokorzenia w imię miłości do drugiego człowieka. Taka sytuacja przypomina przedstawiony przez Annę Achmatową w słynnym poemacie Requiem, obraz kobiet stojących w wielogodzinnych kolejkach do urzędów i więzień w oczekiwaniu na uzyskanie jakiejkolwiek wiadomości o aresztowanych synach i mężach - kobiet, które zostały przyrównane przez poetkę do Matki Boskiej Bolesnej. Sołżenicyn okazuje podobne uszanowanie dla losu matek i żon zeków, który w wielu przypadkach jest równie ciężki jak los samych uwięzionych. Powołaniem tych kobiet jest zachowanie pamięci o normalnym życiu, można powiedzieć - „przechowanie” czy „ratowanie” życia. Dlatego Rita Brackman określa żeńskie postaci przedstawione przez Sołżenicyna w powieści Krag pierwszy „wybawicielkami” (ros. спасительниць) [Бракман 1983, 67].

Warto zwrócić uwagę, że w wielu wypadkach to, co zostało tu nazwane świętością kobiecą u Sołżenicyna jest w istocie obrazem heroicznej walki z trudną codziennością i własnymi słabościami. Ukazane przez proza- 
ika kobiety ulegają wszelkiego rodzaju pokusom i poddają się presji świata, a jednak w jakiś sposób zachowują zupełnie niepojętą czystość duszy, która czyni je otwartymi na ludzki ból i wiernymi wybranej drodze życiowej. Właśnie cierpienie jest, jak się wydaje, kwestią wyróżniająca kobiety, które w utworach Sołżenicyna utożsamiają chrześcijańskie cnoty. Jest to zarazem odmiana ruskiego tradycyjnego typu cierpiętnika, (,strastotierpca”) - człowieka, który przyjmuje mękę, poniżenie, a nawet śmierć. Ten typ duchowy bardzo przypomina słynny literacki obraz Soni Marmieladowej z powieści Zbrodnia $i$ kara Fiodora Dostojewskiego, kontynuację którego można znaleźć w literaturze dwudziestowiecznej na przykład w utworach Siostry krzyżowe Aleksego Riemizowa lub Złoty wzór Borysa Zajcewa. Ów specyficzny typ świętości rozpoznał w twórczości Sołżenicyna John Dunlop analizując postaci bohaterów występujących w dziele Archipelag Gułag (Apxuneлaz ГУЛаг, 1973-76). Według amerykańskiego uczonego główną cechą wyznaczonego modelu świętości jest nie tylko akceptacja cierpienia, ale także postawa „moralnego protestu”, to znaczy sytuacja, kiedy człowiek nie zgadzając się wewnętrznie z rzeczywistością akceptuje niesprawiedliwie przypadające mu w udziale cierpienie. Takie zachowanie, według Dunlopa, Sołżenicyn ceni wyżej niż otwarty sprzeciw, a źródła podobnej postawy tkwią w prawosławnej tradycji duchowej:

Хотя Солженицын искренне сочувствует стихийным выступлениям бесстрашных людей, ему самому по духу гораздо ближе протест чисто моральный. Такая форма сопротивления злу характерна для восходящей к святым Борису и Глебу русской духовной традиции, основанной на идеях непротивления злу и самопожертвования. Солженицын, по-видимому, различает два типа духовного сопротивления несправедливости и все-проникающей лжи - инстинктивное, когда человек отказывается лгать вместе со всеми, просто встаёт и говорит: «Нет!»- и продиктованное мировоззрением [Данлоп 2010, 410].

Owa nietypowa świętość nie oznacza życia bez grzechu, ale gotowość służenia innym, przyjmowania cierpienia i przebaczenia win. O cnotliwości człowieka, niezależnie od grzechów, które popełnił w przeszłości, decyduje bowiem to, jak odnosi się on do innych ludzi i jak przyjmuje swoje życie. Można nawet powiedzieć, że grzech jest kolejnym cierpieniem, które święty człowiek dobrowolnie przyjmuje na siebie po to, aby pomóc innym w osiągnięciu zbawienia. Tę w istocie graniczną wersję świętości, kiedy człowiek godzi się przyjąć na siebie piętno grzeszności, Sołżenicyn wprowadza wprost w cyklu powieściowym Czerwone Koło (Красное Колеco, 1971-1991). W jednym z nieco oderwanych tematycznie od reszty utworu 
rozdziałów, wprowadzających w prywatne doświadczenia pojedynczych bliżej nieznanych osób, Sołżenicyn przybliża mistyczne przemyślenia pewnej kobiety. Ukazana jest ona w sytuacji rozpamiętywania swoich błędów i żalu za grzechy. Narrator zrazu pokazuje ją w owej scenie bez wstępnego przedstawienia jej historii - wiadomo jedynie, że kobieta ma na imię Zina. Dopiero później bardzo pobieżnie, w formie wewnętrznej spowiedzi, zarysowane zostają niektóre momenty z przyszłości dziewczyny, uznanej przez środowisko za upadłą kobietę i wyrodną matkę. Zina ze skruchą, ale także z poczuciem wielkiej odpowiedzialności stwierdza:

Святой - быть легко. Но грешную понять невозможно. Женщине не испытавшей - понять испытавшую невозможно [Солженицын 2006, 520].

W tej wypowiedzi Sołżenicyn jasno ukazuje, że grzech Ziny powinien być rozpatrywany w perspektywie cierpienia, którego doświadcza grzesznik zdając sobie sprawę, że swoim postępowaniem skrzywdził innych ludzi. Przewinienia wobec innych są tu przedstawione jako bagaż doświadczeń, które jak niegojąca się rana ciągle sprawiają Zinie ból. Grzech jest więc tu trudnym doświadczeniem, które paradoksalnie może doprowadzić na wyższy stopień rozwoju duchowego. Staje się on swoistą ofiarą, którą Zina akceptuje w imię miłości. W postaci wzgardzonej i cierpiącej z powodu swoich przewin kobiety zawiera się więc swoista wersja błogosławionej winy - felix culpa. Idei, która, prócz wspomnianych wyżej pisarzy (Dostojewskiego czy Riemizowa), zainspirowała wielu myślicieli rosyjskich, w tym na przykład Mikołaja Bierdiajewa czy Lwa Szestowa [Špidlik 2000, 307].

Trzeba przyznać, że Sołżenicyn nie stosuje jednak nigdy gotowych schematów i w swoich odwołaniach do tradycji zawsze wprowadza pewien własny rys, dodatkowy element, który sprawia, ze jego podejście do tematu jest nowe i indywidualne. Wystarczy spojrzeć na inne typy kobiecej świętości, ukazane w epopei Czerwone Koło. Wśród setek przedstawionych tam postaci można znaleźć liczne przykłady kobiet, które poświęciwszy swoje osobiste ambicje dla dobra rodziny, przyjmują pokornie los odrzuconych i zapomnianych żon w imię kariery zawodowej mężów lub też zgadzają się na życie w poniżeniu z powodu miłości do ukochanego mężczyzny. $\mathrm{W}$ istocie losy przedstawionych kobiet przypominają chwilami fabuły tanich romansów. Jednak w obyczajowych perypetiach bohaterek na czoło wysuwa się nie miłość czy szczęście, ale właśnie ofiara, żal lub świadome poświęcenie. Można powiedzieć, że Sołżenicyn po prostu w losie kobiety odnajduje cechy, które predestynują ją do świętości - oznaczającej w tym miejscu poświęcenie i zgodę na wszelkie trudy. Takim właśnie typem kobiety gotowej do przyjęcia cierpienia jest Likonia, która wyrzeka się niezależności i pozy- 
cji w towarzystwie w imię miłości do żonatego mężczyzny. Zaś młodziutka Wiera staje się ofiarą gwałtu w imię ideałów rewolucyjnych. Wobec tego, trudno się nie zgodzić ze stwierdzeniami niektórych badaczy twórczości Sołżenicyna, że świat w Czerwonym Kole jest rządzony przez mężczyzn. Rola kobiet jest rzeczywiście drugoplanowa i sprowadza się w większości przypadków do wypełniania obowiązków rodzinnych i zapewnienia opieki dzieciom. Lecz funkcje te traktowane są przez Sołżenicyna z wielką powagą i ukazane w jego epopei kobiety w rzeczywistości odznaczają się wielkim heroizmem moralnym. W kobiecości przedstawionej przez Sołżenicyna jest coś mistycznego, co pozwala skojarzyć jego pojmowanie owego fenomenu z poglądami Włodzimierza Sołowjowa. Sołowjowowska „Wieczna Kobiecość” [Sołowjow 2002, 32-45] jest zresztac przywołana w Czerwonym Kole na zasadzie zaprzeczenia. Tzw. „Nowa Kobieta” lansowana przez Aleksandrę Kołłątaj jest w istocie odwrotnością maksymalistycznego, heroicznego obrazu, do którego odwołuje się Sołżenicyn w konstruowaniu postaci współczesnej świętej-cierpiętniczki. Wypowiadane przez Kołłątaj hasła emancypacji moralnej kobiet są przedstawione przez narratora cyklu z dużą dozą ironii, a sam typ kobiety skoncentrowanej na swoich potrzebach seksualnych zostaje w Czerwonym Kole po prostu wyśmiany.

Podobnie w charakterze kontrastu Sołżenicyn przywołuje także obraz świętej oficjalnie kanonizowanej przez cerkiew prawosławną - cesarzowej Aleksandry Fiodorowny. W odróżnieniu jednak od całej rzeszy kobiet cierpiących, w stosunku do tej postaci narrator zachowuje rezerwę. Na pewno w figurze imperatorowej docenione jest jej oddanie mężowi i dzieciom, jednak prócz tego narrator akcentuje cały szereg negatywnych cech, które z trudem można zaakceptować u postaci oficjalnie uznanej za świętą. Aliks jest bowiem zazdrosna, dumna, skłonna raczej do dewocji niż prawdziwej religijności, nie stroni od intryg i łatwo popada w rozdrażnienie, a ze względu na swoją przesądność staje się częstą ofiarą różnego typu szarlatanów. W tym obrazie trudno znaleźć cechy uzasadniające wyniesienie rosyjskiej cesarzowej na ołtarze, aż do momentu, gdy dotyka jej prawdziwe cierpienie w postaci odrzucenia ze strony własnych poddanych, po abdykacji Mikołaja II. Sołżenicyn zresztą uzupełnił charakterystykę rodziny carskiej zawartą w Czerwonym Kole pewnymi wypowiedziami publicystycznymi. W jednej $\mathrm{z}$ nich stwierdził:

А канонизация царской семьи у меня лично как человека, много занимавшегося историей России, встречает противодействие вот в каком отношении. Ведь канонизация царской семьи происходит не в равномерном ряду десятков тысяч погубленных, она выделяет царскую семью на первостепенное место [Струве, Москвин 2005, 39]. 
Bohaterki Sołżenicyna niezwykle rzadko przedstawione są w kontekście, który można uznać za religijny, lecz nie wyklucza to swoistego mistycyzmu owych obrazów. Analizowane wyżej postaci z utworów pisarza nie realizują ściśle dawnych wzorców świętości kobiecej i często oddalają się one od ustalonych schematów, ale przez to zawierają więcej elementów uniwersalnych. W tak sformułowanym charakterze Sołżenicynowskich kobiet można odnaleźć powiązania z różnymi postaciami kobiecymi znanymi z literatury rosyjskiej. Dokładniejsze przeanalizowanie tych odniesień zapewne wydatnie uzupełniłoby powyżej przedstawione rozważania. Można ogólnie stwierdzić, że zmodyfikowany obraz kobiety prawej i cierpiącej doszedł do Sołżenicyna przez długą rosyjską tradycję duchową - ludową i literacką - jednak pisarz uzupełnił go własnymi elementami. Kobieca dola, pełna niepewności, obawy o bliskich i wiernego oczekiwania, jest według twórcy dobrym punktem wyjścia do osiągnięcia nieoficjalnej, codziennej wersji świętości, w której główną rolę odgrywa cierpienie i służba na rzecz innych. Przywoływanie takich wzorców ma na pewno znaczenie terapeutyczne, niezmiernie aktualne w czasach upadku tradycyjnych wartości, dlatego w sumie można Sołżenicynowskie obrazy współczesnych prawiednic i cierpiętnic uznać za swego rodzaju drogowskazy w świecie, gdy „ludzie zapomnieli Boga".

\section{Literatura}

Andrusiewicz A., 1994, Mit Rosji. Studia z dziejów i filozofii rosyjskich elit, t. I, Rzeszów.

Bebis E., 1999, Święci Kościoła, [w:] Prawostawie. Światto wiary i zdrój miłosierdzia, red. K. Leśniewski, J. Leśniewska, Lublin.

Charewicz J., 2013, Wspótczesny stan badań nad prawostawna hagiologia, „Elpis” XV (XXVI), z. 27 (40), s. 129-137.

Clément O., 2012, Solżenicyn na nowo odczytany, przeł. K. Rottenberg, Warszawa.

Kowalska M., 2011, Aleksander Solżenicyn: homo sovieticus i człowiek sprawiedliwy, Toruń.

Literatura staroruska. Wiek XI-XVII. Antologia, 1971, opr. W. Jakubowski i R. Łużny, Warszawa.

Przebinda G., 2003, Między Moskwa a Rzymem. Myśl religijna w Rosji XIX $i$ XX wieku, Kraków.

Sidor M., 2009, Rosja i jej duchowość. Proza „pierwszej fali” emigracji rosyjskiej, Lublin. 
Sidor M., 2012, Aktualizacja staroruskiego obrazu świeckiego naśladowcy Chrystusa w postaciach kobiecych prozy dwudziestowiecznej (utwory Aleksego Riemizowa i Aleksandra Sołżenicyna), [w:] Chrześcijański Wschód i Zachód. Formy dialogu. Wzory kultury. Kody pamięci, red. I. Lis-Wielgosz, W. Jóźwiak, Poznań, s. 419-429.

Sołowjow W., 2002, Sens miłości, tłum. H. Paprocki, Kęty.

Špidlik T., 2000, Myśl rosyjska. Inna wizja człowieka Inna wizja człowieka, przeł. J. Dembska, Warszawa.

Suchanek L., 1994, Aleksander Solżenicyn. Pisarz i publicysta, Kraków.

Suchanek L., 2013, Filozofia polityczna Aleksandra Sotżenicyna, [w:] Kultura literacka emigracji rosyjskiej, ukraińskiej i białoruskiej XX wieku. Konteksty estetyka - recepcja, red. A. Woźniak, Lublin.

Wodziński C., 2000, Św. Idiota. Projekt antropologii apofatycznej, Gdańsk.

Żejmo B., 2000, Problemy etyczne we wspótczesnej prozie i publicystyce rosyjskiej. Lata 60.-90., Łódź.

Аверинцев С. С., 1988, Византия и Русь: Два типа духовности, „Новый мир” № 9, s. 227-239.

Бракман Р., 1983, Выбор в аду: жизнеутверждение солженицьнского героя, Ann Arbor.

Данлоп Дж. Б., 2010, «Архипелаг ГУЛАГ»: Альтернатива идеологии, [в:] Солженицын: Мыслитель, историк, художник. Западная критика: 1974-2008, red. Э.Э. Эриксон, Русский путь, Москва.

Иеромонах Иоанн (Кологривов), 1961, Очерки по истории русской святости, Брюссель.

Лакшин В., 2009, Александр Солженицьн и колесо истории, сост. С. Н. Кайдаш-Лакшина, Москва.

Лихачев Д.С., Панченко А.М., Понырко Н.В., 1984, Смех в Древней Руси, Ленинград.

Лопухина-Родянко Т., 1974, Духовные основь творчества Солженицьна, Frakfurt/Main.

Солженицын А., 2009, В круге первом, Москва.

Солженицын А. И., 1995, Публицистика: в трех томах, сост. и пояснения Н. Солженицыной, т. 1, Статьи и речи, Ярославль.

Солженицын А. И., 2005, Беседа с Витторио Страда. 20 октября 2000, [в:] Между двумя юбилеями (1998-2003), Писатели, критики и литературоведь о творчестве А.И. Солженицьна, ред. Н.А. Струве, В.А. Москвин, Москва.

Солженицын А.И., 2006, Собрание сочинений в 30 томах, т. 10, Октябрь Шестнадиатого, Москва.

Темпест Р., 2013, Фермопиль Георгия Воротьнцева: солженицынская концепиия мужественности, [в:] Жизнь и творчество Александра Солжениивьна: на пути $\kappa$ „Красному Колесу”, ред. Л. Сараскина, Москва. 
Топоров В. Н., 1995, Святость и святье в русской духовной культуре, t. 1, Москва.

Урманов А.В., 2000, Поэтика прозы Александра Солжениџына, Москва.

Урманов А.В., 2005, Кониепция эроса в творчестве А. Солженицьна, [в:] Между двумя юбилеями (1998-2003), Писатели, критики и литературоведь о творчестве А.И. Солженицына, ред. Н.А. Струве, В.А. Москвин, Москва.

Федотов Г. П., 1990, Святые древней Руси. X-XVII cm., вступ. Д. С. Лихачев, А. В. Мень, Москва.

\section{SUFFERING AND RIGHTEOUSNESS. THE RUSSIAN VERSION OF FEMALE HOLINESS}

\section{S U M M A R Y}

The article deals with the issue of religious interpretation of A. Solzhenitsyn's works of art. The reason for this kind of research consists in the writer's interviews and essays where he presented his attitude toward religion. The author of the paper focuses on the issue of holiness in its feminine version. The examples of saint women could be observed even in the first Solzhenitsyn's writings, but because of political and ideological situation in the writer's native country critics used to consider such themes in the context of national folk ethic.

The analyses show that folk sense of righteousness is an inseparable element of Solzhenitsyn's ethical conception, but it is always combined with Russian Orthodox religious tradition. 